KAROLINA WARZOCHA*

\section{Od „ziemi niczyjej” do półprywatnych ogródków przydomowych - tereny zielone krakowskich osiedli mieszkaniowych}

\author{
From the "no-one"s land" to the semi-private \\ backyard gardens - the green areas \\ on the housing estate in Cracow
}

Streszczenie systemowej w Polsce. Analizie poddano osiem osiedli mieszkaniowych, które powstały na terenie Krakowa w różnych dekadach. Przy ocenie zwrócono uwage przede wszystkim na funkcje i walory estetyczne terenów zielonych, ich powierzchnie w stosunku do ilości mieszkań oraz dostęp do tych przestrzeni. Które rozwiązania sprzyjają zacieśnianiu więzi sąsiedzkich, umacniaja identyfikacje z miejscem zamieszkania oraz poczucie bezpieczenstwa i odpowiedzialności? Czy po dekadach doświadczeń, mnożenia dobrych i złych koncepcji, możliwe jest powstanie „osiedla idealnego”, które będzie przyjazne, zielone i słoneczne nie tylko z nazwy?

Abstract

The aim of this article is to assess the changes in designing of the collective housing estate spaces that have occurred after the system transformation in Poland. Eight Cracovian housing estates designed in various decades, have been analyzed. The attention was paid to the functions and the aesthetic values of the green areas, their quantity in relation to the number of the apartments and tion with the place of residence, a sense of security and responsibilyz Afer decales of experience, mulliplication of good and bad concepts, is it possible to create an "ideal housing estate" that will be friendly, green and sunny, not just in name?

Stowa kluczowe: tereny zielone, pótprywatne ogródki przydomowe, osiedle mieszkaniowe

Keywords: green areas, semi-private backyard gardens, housing estate

Krakowski rynek pierwotny nieruchomości pełen jest deweloperskich inwestycji, ktore swoja nazwą i wyidealizowanymi wizualizacjami mają zachęcić potencjalnych klientów do skorzystania z oferty. Inwestycje w swoim nazewnictwie często zawierają słowa: park, ogród, zacisze, garden ( $z$ ang. ogród) lub przymiotniki: słoneczny, zielony. Można zamieszkać pod dębami, modrzewiam czy orzechem. ' Krakow nie jest w tej kwestii odosobniony. W każdym większym mieście Polski sytuacja na rynku deweloperskim przedstawia się podobnie. Atrakcyjna nazwa w połączeniu $z$ wizualizacją inwestycji skąpanej w zieleni może wywołać u odbiorcy mylne wrażenie, które później zweryfikuje rzeczywistość

Potrzeba człowieka obcowania z naturą jest powszechnie znana i nie budzi wątpliwości. Rola zieleni, w szczególności na terenach zurbanizowanych, jest nieoceniona. Należy tu

The primary real estate market in Cracow is full of de. ers to the offer. The investments' nomenclature often contains the words like "park", "garden", "seclusion" or adjectives like "sunny", "green". You can settle down "under" the oaks, larches or walnut tree'. Cracow is no "xception. The development market situation is similar with the visoralization of a An attractive name combined with the visualization of an investment bathed in greenwhich will be verified by the reality.

The human need to associate with nature is widely known and does not raise any doubts. The ride the greenery is invaluable especially in urban areas. All social, ecological, aesthetic, didactic and educaAlional functions should be mentioned. Human's con- wymienić przede wszystkim funkcje społeczne, ekologiczniweluje stres, który stał sie nieodłącznym składnikiem wspołczesnego życia. Tereny zieleni to możliwosc wypoczynku, rekreacji i nawiązywania kontaktów międzyludzkich. Obecnie, przy rosnacej swiadomości ekologicznej oraz popularyzacji idei zrównoważonego rozwoju, bliskośc terenow przyrodniczych stawia się na rowni z warunkami mieszkaniowymi, czy dostepnoscią do podstawowych usług. Obecność terenów zielonych w miejscu zamieszkania czy pracy, stała sie ważnym czynnikiem wpływającym na jakość i komfort życia w mieście. [3]

Rewolucja przemysłowa i związany z nią gwałtowny, często niekontrolowany rozwój miast, znacząco ograniczy dostęp mieszkancow do srodowiska naturalnego. Probem dostrzezono na poczatku XX wieku, czego dowodem były nowe koncepcje urbanistyczne (idea "miasta-ogrodu" E. Howarda) ${ }^{2}$ oraz zapisy Karty Ateńskiej ${ }^{3}$ (IV CIAM, 1933 r.). Powojenny deficyt mieszkaniowy wywolany zniszczeniami wojennymi oraz migracja ludności ze wsi do miast, dał polskim urbanistom możliwość wprowadzenia zasady stonce, przestrzen, zielen" ${ }^{\prime \prime}$ przy projektowaniu nowych terenów mieszkaniowych. Owczesny ustrój polityczny sprawiał, iż nie musieli oni liczyć się z wartościa gruntu pod zabudowe. Osiedla projektowano $z$ rozmachem, w sposób kompleksowy [2]. Powstawaly zespoły budynkow mieszkalnych z zapleczem usług potrzebnych na co dzień (sklepy, szkoły, przedszkola) a rozległe tereny między nimi stanowić miały miejsce wypoczynku i rekreacji. Transformacja systemowa, która nastąpiła w Polsce w 1989 roku, zmieniła sposób projektowania osiedli mieszkaniowych. Rynek nieruchomości przejęli prywatni inwestorzy, a postępująca liberalizacja prawa budowlanego w sprawie minimalnych odległośc między budynkami, tylko pogorszyła sytuacje [6] .

Celem niniejszego artykułu jest ocena zmian, jakie zaszły po 1989 roku, w projektowaniu wspólnej przestrzen osiedlowej. Analizie poddano 4 osiedla, które powstały na terenie Krakowa po II wojnie światowej, do lat $80-$ tych (os. Willowe, os. Spółdzielcze, os. Dywizjonu 303 , os. Lipińnkiego) oraz 4 zespoły mieszkaniowe zrealizowane po zmianie ustroju (os. Pszona, os. Europejskie Nowe Czyżyny, Bagry Park). Przy ocenie zwrócono uwagę przede wszystkim na funkcje i walory estetyczne terenów zielonych, ich powierzchnię w stosunku do ilośc mieszkañ ${ }^{5}$ oraz dosteep do tych przestrzeni. Które rozwiazania sprzyjają zacieśnianiu więzi sąsiedzkich i umacniają identyfikację z miejscem zamieszkania, a które prowadza do powstawania tzw. „ziemi niczyich”, pustych , zaniedbanych a czasem zdewastowanych?

Poszukując przykładów do analiz, już na samym początku, autor zetknał sie z problemem jakim jest zdefiniowanie terminu "osiedle". Socjolog miasta W. Mirowski wyróżnia cztery aspekty, które należy wziać pod uwagę próbując odpowiedzieć na pytanie „czym jest osiedle mieszkaniowe?". Jest to aspekt urbanistyczny, inwestycyjny, administracyjny i społeczny [7]. Do końca lat 80-tych osiedlam nazywano całe układy przestrzenne z budynkami miesz- tact with the nature affects his well-being positively give a possibility to rest, recreation and establishing interpersonal contacts. Nowadays, with the growing ecological awareness and popularization of the idea of sustainable development, he proximity of natura areas is equal to the housing conditions and accessibility to basic services. The presence of green areas important factor affecting the quality and comfort of living in the city. [3]

The uncontrolled and rapid development of the cit ies, as a consequence of the industrial revolution, had reduced the access to the natural environment significantly. The problem was noticed at the beginning of the 20th century, as evidenced by new urban concepts (the idea of "the garden city" by E. Howard) ${ }^{2}$ and the Athens Charter ${ }^{3}$ (4th CIAM, 1933). The post-war housing deficit caused by war damages and the human's migration from villages to cities, gave to Polish urban planners the opportunity to insert the principle of "sun, space and greenery" while designing new residential areas. They did not have to reckon with the value of investment land thanks to the political system. The housing estates were designed with impetus and in a comprehensive way [2]. The complexes of residential buildings were designed with facilities Tor everyday services (shops, schools, kindergartens). a place for rest and recetion. The system traformation in Poland in 1989 ch nnged the way of housing estates designing. The real estate market has been taken over by private investors. In addition the situation has aggravated by the progressive liberalization of the building law regarding the minimum distances between buildings [6].

The aim of this article is to assess the changes in designing of the collective spaces of housing estates that have occurred after the system transformation in 1989. The analysis includes four housing estates that were built in Cracow after the 2nd World War up to the 1980s (Willowe Estate, Spoidzielcze Estate, Dywizjonu 303 Estate, Lipińskiego Estate) and four housing complexes created after the system chang (Pszona Estate, Europejskie Estate, Nowe Czyżyny, Bagry Park). The attention was paid to the functions and the aesthetic values of the green areas, their and the in relation the the of the or the apartments and the access to these spaces. Which solutions are contiferion with the phace of residence, and which solutions load to the so-called "no-one's land" - empty, neglected and devastated sometimes?

Looking for examples for analysis, the author came across the problem of defining the term "housing estate" at the beginning. The sociologist of the city W. Mirowski distinguishes four aspects that should be taken into account while trying to answer the question "what is a housing estate?". It is a urban investment, administrative and social aspect [7]. Until the end of the 1980s, the housing estate was 
kalnymi, usługami i przyległymi terenami rekreacyjnymi, którymi zarządzała spółdzielnia (aspekt urbanistyczny i administracyjny). Obecnie to pojęcie może odnosić się do niewielkiej inwestycji złożonej z kilku budynków, pozbawionych jakichkolwiek usług, którą zamieszkuje niespełna pół tysiąca osób (aspekt inwestycyjny). W takim wypadku pojęcie "osiedla" wydaje sie być nadużywane, a bardziej adekwatnym terminem jest „zespół mieszkaniowy" [7]. Na cele niniejszego artykułu autor będzie posługiwał się terminem „osiedle", niezależnie od złożoności układu przestrzennego i ilości mieszkańców. Analizie poddano krakowskie osiedla, które powstały po II wojnie światowej, w różnych dekadach oraz przy zastosowaniu odmiennych technologii budowlanych. Najstarszym wybranym przykładem jest Osiedle Willowe powstałe w latach 50-tych, we wschodniej czesści Nowej Huty, jeszcze przed wytyczeniem ostatecznego planu miasta6. Osiedla, które powstały w czasach normatywów urbanistycznych oraz świetności technologi wielkopłytowych prefabrykatów to Osiedle Spółdzielcze, Lipińskiego i Dywizjonu 303. Analizowane Osiedle Pszona jest przykładem zespołu mieszkaniowego z la 90-tych. Najnowsze, to osiedla nadal rozwijające się, jak Nowe Czyżyny i Osiedle Europejskie.

Osiedla zbadano pod względem procentowego udziału terenów zabudowy oraz obszarów zielonych w stosunku do całości inwestycji. Wzięto pod uwage również tereny rekreacyjne $w$ bezpośrednim otoczeniu zabudowy, jak dostępne dla mieszkańców place zabaw. W przypadku osiedli starszych, nie uwzględniono terenów szkół i przedszkoli, przynaleznych do danych obszarow (Os. Willowe Os. Spółdzielcze) oraz parków bezpośrednio graniczących z osiedlem (Os. Spółdzielcze, Os. Dywizjonu 303). Analize poszerzono o wyliczenie współczynnika powierzchni zielonej przypadającej na jedno mieszkanie (Tabela 1).

Sprawiedliwe porównanie terenów zielonych osiedli tak różnych wiekowo, jest bardzo trudne. Należy pamiętać, iż roślinność, zwłaszcza wysoka, potrzebuje czasu, aby w pełni się rozwinąć. Archiwalne fotografie nowohuckich osiedli mieszkaniowych dowodza, iż nie powstały one wśród bujnej zieleni, jak Sady Zoliborskie Haliny Skibniewskiej [4], ale na pustych terenach. Dopiero ich odpowiednie zagospodarowanie i kolejne mijajace dekady, dały efekt, który można dziś obserwować. Osiedl te, wydają się „tonąç" w zieleni. Roślinność, poza długim okresem na rozrost, dostała przede wszystkim sprzyjajace ku temu warunki. Duża przestrzeń między budynkam i brak podziemnych kondygnacji poza obrysem zabudowy, pozwolity rozwinąć się nawet najbardziej wymagajacym gatunkom drzew. Jak wynika z rozmów przeprowadzonych wśród starszych mieszkańców analizowanych osiedli, większość drzew oraz innych form roślinności została zasadzona $z$ ich inicjatywy, aby stworzyć miejsca zacienione, idealne do wypoczynku i rozrywek sasiedzkich? (il.1) W ówczesnych latach była to najbardziej popularna forma spedzania wolnego czasu, dostepn dla wszystkich. Dziẹki dobrze przemyślanym i zaprojektowanym układom przestrzennym, między budynkam tworzyły sie tereny sprzyjające rekreacji i nawiazzywa- meant as a spatial layout with residential buildings, by the housing associations (urban and administrative aspects). Currently, this term may refer to a sma investment of several buildings deprived of any se vices, with half a thousand inhabitants (investmen aspect). In this case, the term "housing estate" seems to be abused. The term "housing complex" is more adequate [7]. For the purposes of this article, the au the number of inalexity of the

The analysis refers to the Cracovian housing estate ades and in different 2nd World War, in different deoldest chosen example is the Willowe Estate, built in the 1950s, in the eastern part of Nowa Huta before the final plan of the city was delineated ${ }^{6}$. Spółdzielcze Estate, Lipińskiego Estate and Dywizjonu 303 Estate are the settlements that were created in the times of spatial planning standards and in the years of popu larity of the prefabrication technologies. The analyzed szona Estate is an example of a housing complex from the 90s. The newest examples, such as Nowe Czyżyny and Europejskie Estate, are still developing

investments.
The estates were investigated in terms of the percentage share of building areas and green areas in relation the entire investment space. Recreational areas in

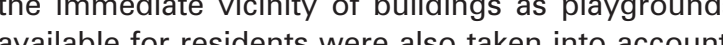
the case of older spaces, the areas of schools and kindergartens belonging to the housing estates (Willowe Estate, Spółdzielcze Estate) and parks directly adjacent to the housing estates (Spółdzielcze Estate, Dywizjonu 303 Estate) were not taken into account. The analysis was extended by calculating the green area coefficient per one flat (Table 1).

It's very difficult to fairly compare the green areas on the different-aged housing estates.

th should be remembered that especially high vegetation needs time to develop fully. Archival photographs of Nowa Huta housing estates prove that they didn't arise among lush greenery, such as Sady Zoliborskie by Halina Skibniewska [4], but were buit on empty areas. The effect that can be observed today is the result of the appropriate management and following decades. These settlements seem to be drowned" in greenery. Vegetation, except for a long period of growh, got all favorable conditions. The derground storey beyond the outline of the buildinge allowed to develop even the most demanding species of trees. The interviews conducted among the older residents of the analyzed settlements revealed that most of the trees and other forms of vegetation were planted on their initiative to create shady plac es, ideal to rest and neighborhood entertainments (ill.1). It was the most popular form of spending free time, available to everyone. Thanks to well-thoughtout and designed spatial layouts, areas that promote recreation and establishing interpersonal contacts
Tabela 1. Opracowanie wtasne. Wszelkie dane liczbowe zawarte $w$ tabeli pochodzą z autorskich pomiarów, inwentaryzzaciji i wizji lokalnych,

\begin{tabular}{|c|c|c|c|c|c|c|c|c|}
\hline Ip & nazwa osiedla & $\begin{array}{l}\text { okres po- } \\
\text { wstania }\end{array}$ & lokalizacja & $\begin{array}{l}\text { pow. } \\
\text { osiedla [ha] }\end{array}$ & $\begin{array}{c}\text { pow. } \\
\text { zabudowy } \\
{[\%]}\end{array}$ & $\begin{array}{c}\text { pow. zieleni } \\
{[\%]}\end{array}$ & $\begin{array}{c}\text { ilosść } \\
\text { mieszkań }\end{array}$ & $\begin{array}{l}\text { pow. zieleni przypa- } \\
\text { dajaca ana } 1 \mathrm{miesz}- \\
\text { kanie }\left[\mathrm{m}^{2}\right]\end{array}$ \\
\hline 1. & Osiedle Willowe & 1949 - 1952 & $\begin{array}{l}\text { Dzielnica XVIII } \\
\text { Nowa Huta }\end{array}$ & 11,54 ha & $16.13 \%$ & $53 \%$ & 478 & 99,6 \\
\hline 2. & $\begin{array}{l}\text { Osiedde } \\
\text { Spółdzielcze }\end{array}$ & 1960 - 1962 & $\begin{array}{l}\text { Dzielnica XVIIII } \\
\text { Nowa Huta }\end{array}$ & 8,2 ha & $15.8 \%$ & $50.42 \%$ & 666 & 62,1 \\
\hline 3. & $\begin{array}{l}\text { Osiedle } \\
\text { Dywizjonu } 303\end{array}$ & lata 70/80 & $\begin{array}{l}\text { Dzielnica XIV } \\
\text { Czyżyny }\end{array}$ & 10,47 ha & $12.55 \%$ & $57.84 \%$ & 1060 & 57,2 \\
\hline 4. & $\begin{array}{l}\text { Osiedle } \\
\text { Lipinskiego }\end{array}$ & 1984 - 1985 & $\begin{array}{l}\text { Dzielnica VIII } \\
\text { Dębniki }\end{array}$ & 5,57 ha & $12.79 \%$ & $49.09 \%$ & 491 & 55,7 \\
\hline 5. & Osiedle Pszona & 1995 - 1999 & $\begin{array}{l}\text { Dzielnica III Prad- } \\
\text { nik Czerwony }\end{array}$ & 5,08 ha & $22.68 \%$ & $41.38 \%$ & 392 & 53,7 \\
\hline 6. & $\begin{array}{l}\text { Osiedle } \\
\text { Europejskie }\end{array}$ & 2002 -obecnie & $\begin{array}{l}\text { Dzielnica VIII } \\
\text { Dębniki }\end{array}$ & 11,57 ha & $25.8 \%$ & $31.51 \%$ & 1830 & 19,9 \\
\hline 7. & Bagry Park & $2014-2017$ & $\begin{array}{c}\text { Dzielnica XIII Pod- } \\
\text { górze }\end{array}$ & 7 ha & $27.86 \%$ & $41.37 \%$ & 696 & 41,5 \\
\hline 8. & Nowe Czyżyny & $\begin{array}{l}2014 \text { - obec- } \\
\text { nie }\end{array}$ & $\begin{array}{l}\text { Dzielnica XIV } \\
\text { Czyżyny }\end{array}$ & 13,43 ha & $20.5 \%$ & $31.32 \%$ & 3314 & 12,7 \\
\hline
\end{tabular}

Table 1. Self - analyzed. All figures contained in the table come from the author's measurements, inventory and local visions, supported by

\begin{tabular}{|c|c|c|c|c|c|c|c|c|}
\hline & housing estate & building years & localization & $\begin{array}{l}\text { estate area } \\
\text { [ha] }\end{array}$ & $\begin{array}{l}\text { building } \\
\text { area [\%] }\end{array}$ & $\begin{array}{l}\text { greenery } \\
\text { area [\%] }\end{array}$ & $\begin{array}{c}\text { number of } \\
\text { flats }\end{array}$ & $\begin{array}{l}\text { greenery area per } \\
\text { one flat }\left[\mathrm{m}^{2}\right]\end{array}$ \\
\hline 1. & Willowe Estate & 1949 - 1952 & $\begin{array}{l}\text { District } \\
\text { Nowa Huta }\end{array}$ & 11,54 ha & $16.13 \%$ & $53 \%$ & 478 & 99,6 \\
\hline 2. & $\begin{array}{l}\text { Spótdzielcze Esta- } \\
\text { te }\end{array}$ & 1960 - 1962 & $\begin{array}{l}\text { District } \\
\text { Nowa Huta }\end{array}$ & 8,2 ha & $15.8 \%$ & $50.42 \%$ & 666 & 62,1 \\
\hline 3. & $\begin{array}{l}\text { Dywizjonu } \\
\text { Estate }\end{array}$ & lata 70/80 & $\begin{array}{l}\text { District XIV Czy- } \\
\text { żyny }\end{array}$ & 10,47 ha & $12.55 \%$ & $57.84 \%$ & 1060 & 57,2 \\
\hline 4. & Lipińskiego Estate & 1984 - 1985 & $\begin{array}{l}\text { District VIII Dęb- } \\
\text { niki }\end{array}$ & 5,57 ha & $12.79 \%$ & $49.09 \%$ & 491 & 55,7 \\
\hline 5. & Pszona Estate & 1995 - 1999 & $\begin{array}{l}\text { District III Prądnik } \\
\text { Czerwony }\end{array}$ & 5,08 ha & $22.68 \%$ & $41.38 \%$ & 392 & 53,7 \\
\hline 6. & $\begin{array}{l}\text { Europejskie Esta- } \\
\text { te }\end{array}$ & 2002 -actually & $\begin{array}{l}\text { District VIII Dẹb- } \\
\text { niki }\end{array}$ & 11,57 ha & $25.8 \%$ & $31.51 \%$ & 1830 & 19,9 \\
\hline 7. & Bagry Park & $2014-2017$ & $\begin{array}{l}\text { District XIII Pod- } \\
\text { górze }\end{array}$ & 7 ha & $27.86 \%$ & $41.37 \%$ & 696 & 41,5 \\
\hline 8. & Nowe Czyżyny & 2014 - actually & $\begin{array}{l}\text { District XIV Czy- } \\
\text { żyny }\end{array}$ & $13,43 \mathrm{ha}$ & $20.5 \%$ & $31.32 \%$ & 3314 & 12,7 \\
\hline
\end{tabular}


niu kontaktów międzyludzkich. Dzieci i młodzież każdą wolną chwile spędzaly "pod blokami", a tak prozaiczne czynności jak wyniesienie smieci, rozwieszanie prania czy trzepanie dywanu, dawały sposobność do podjęcia rozmowy z innymi mieszkancami, a tym samym preteks do dłuższego pozostania w przestrzeni sąsiedzkiej. $\mathrm{Na}$ wspołłczesnych osiedlach mieszkaniowych wysoka zieleń jest praktycznie nieobecna. Częstym usprawiedliwieniem jest fakt, iż inwestycje powstają na dawnych terenach rolniczych, gdzie tej zieleni po prostu nigdy nie było. W innych sytuacjach dokonuje się bezwzględne wycinki drzew, ktorą ułatwia obecnie obowiązujące prawo. W zamian mieszkańcy dostają drzewka wciśnięte w wąskie pasy wzdłuż miejsc parkingowych, które swoją wysokością nie przekroczą drugiego piętra. Brak wysokiej roślinności to nie tylko kwestia czasu. To przede wszystkim brak warunkow na ich rozrost. Tereny przyrodnicze między budynkami to tak naprawdę zielone tarasy, pod którymi ciągną się parkingi. Koniecznośc projektowania podziemnych miejsc postojowych jes bezdyskusyjna, lecz gdy zajmują one cały teren inwestycji, na zieleń wysoką nie ma już miejsca.

To co charakteryzuje starsze osiedla mieszkaniowe, to duże przestrzenie między budynkami. Tereny, które z zatożenia miały być miejscem aktywności i spotkań sassiadów oraz zrekompensować niewielkie mieszkania, dziś stanowia niemały problem. Mówi się o tzw. „ziemiach niczyich" [5]. Są to obszary o dużym potencjale, które ze względów finansowych, administracyjnych lub po prostu braku inicjatywy mieszkańców, pozostaja puste i zaniedbane (il.2). Jednak największe zagrożenie idzie ze strony prywatnych inwestorów, którzy dostają pozwolenie na zabudowę tych przestrzeni. Zwiększa to ilość mieszkańców chętnie korzystających z istniejącej już infrastruktury osiedla, lecz nie dających nic w zamian. Zmienia się układ przestrzenny osiedla funkcjonującego od dekad. Kosztem wspólnych terenów zielonych powstają nowe ogrodzone budynki, co tylko potęguje podziały społeczne.

Obecnie obserwuje się powrót do zabudowy kwartatowej we współczesnej wersji (Nowe Czyżyny, Osiedle Europejskie). Ma to oczywiście podłoże finansowe - takie układy obiektów mieszkalnych pozwalają uzyskac were created between the buildings. Children and me. Prosaic activiti "under the blocks" every spare aundry or flipping a carpet, were giving the opportuity to talk with other residents and a pretext to stay longer in the neighborhood space.

In modern housing estates high greenery is virtually absent. The fact that investments are designed on agricultural areas, where the greenery has never less felling of trees is made, which is facilitated by the currently applicable law, Instead of high greenery, the residents get little trees squeezed into narrow lanes along parking spaces which will not exceed the second floor. Lack of high vegetation is not just a matte of time. First of all, there are no conditions for their growth. Natural lands between the buildings are the green terraces with underground garages in fact. The need to design underground parking spaces is undisputed, but when they occupy the entire investment area, there is no space for high greenery.

The large spaces between buildings are characteristic to the older housing estates. The areas that were supposed to be a place of activity, neighbors' meetings and to compensate for small apartments, are a considerable problem today. They are so-called "no-one's lands" [5]. These are areas with high potential, which, for financial or administrative reason or simply the lack of residents' initiative, remain threaty and neglected (il.2). However, the greatest to build over these spaces. The number of residents increases. New inhabitants are using the existing in frastructure willingly, but without providing anything in return. The spatial layout of the housing estate that was functioning for decades is changing. A new fenced buildings are built at the expense of collective green areas, that only intensifies social divisions. Nowadays, quarterly construction returns but in a contemporary version (Nowe Czyżyny, Europejskie Estate). It has a financial foundation of course - this arrangement of residential allows to obtain the maximum building area of the entire investment space. The buildings' forms create open courtyards

il. 1. Osiedle Lipińskiego - wprowadzenie roślinności i bryte budynku; pomyst i wykonanie - mieszkanka osiedla (autor - K. Warzochal
ill. 1. Lipinskiego Estate - inserting the greenery into the building's form; the idea and realization by a resident of the housing estate

(author - K. Warzocha)

il. 2. Osiedle Spótdzielcze - zaniedbany fragment terenów zielonych (autor $-K$. Warzocha)
iil. 2. Spó́dzzielcze Estate - a neglected part of a green area (author $-K$. Warzocha)
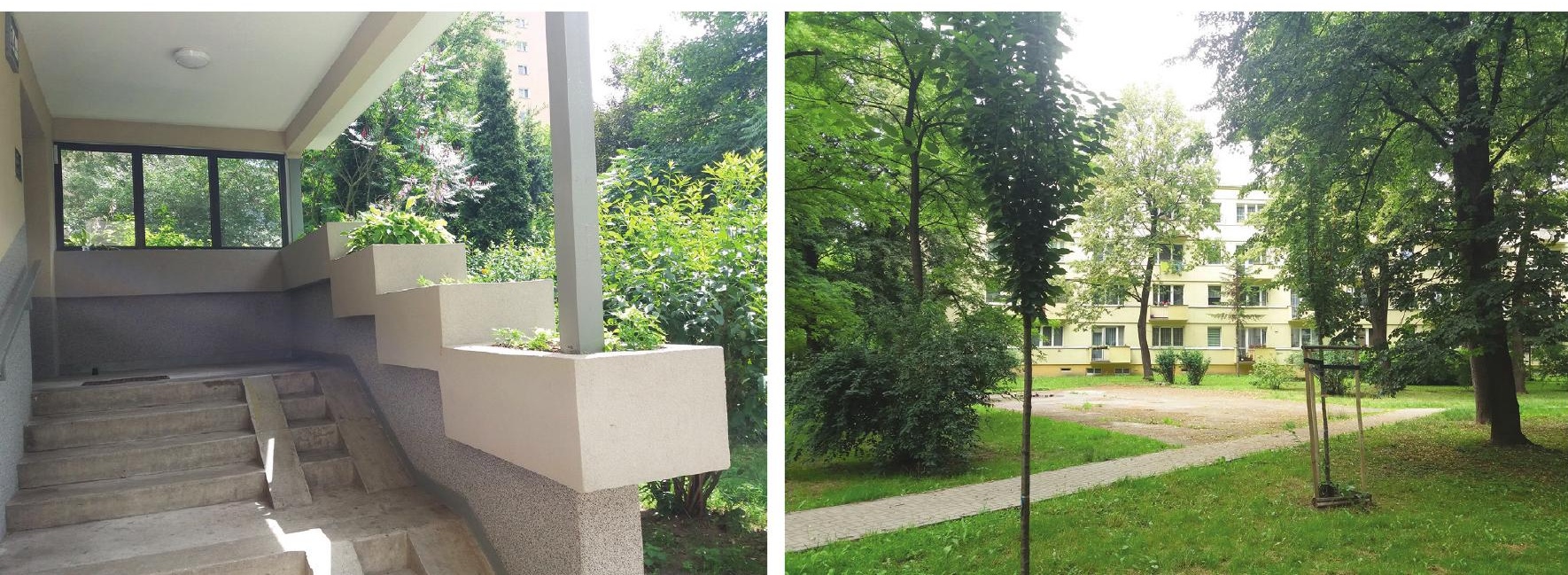

maksymalną powierzchnię zabudowy terenu inwestycji. Formy budynków gacone o zielen i małą architekturę, ktore dają mieszkańcom możliwość wypoczynku w bliskiej odległości zamieszkania. Ten niewielki dystans pelni kluczową rol - łatwo jest wyjśc i wejsc z powrotem w zależności od potrzeb [1], a każde takie wyjscie to okazja do kontaktu z sąsiadami. Istotną kwestią, poza zagospodarowaniem i bliskością wspólnej przestrzeni, jest wysokość budynków otaczających dziedziniec oraz ilosc mieszkancow przypadająca na daną przestrzeń sąsiedzką. Niska, kilkukondygnacyjna zabudowa dodatkowo skraca dystan między mieszkaniem a częscią wspólną, czym ułatwia podjęcie decyzji o wyjściu na zewnątrz. Ma to znaczenie przy każdym rodzaju zabudowy, nie tylko kwartałowej. Im mniejsza ilość mieszkańców przypadająca na dane wnętrze urbanistyczne, tym silniejsza identyfikacja z otoczeniem i poczucie odpowiedzialności za jakość i estetykę wspólnej przestrzeni. Analiza układów przestrzennych wybranych współczesnych osiedli mieszkaniowych ukazuje, iż powierzchnia otwartych dziedzińców w stosunku do ilości mieszkań maleje z każdą inwestycją. W przypadku pierwszych realizacji w zakresie Osiedla Europejskiego od 2002 roku (etap Londyn, Paryż, Rzym), na każde 100 mieszkań przypada 10-13 arów zielonych powierzchn wspólnych. Kolejne etapy (Ateny, Amsterdam, Lizbona) to już 7-9 arów dziedzińca na 100 mieszkań. W jednej z najnowszych inwestycji Krakowa - Nowe Czyżyny wskaźnik ten spada do wartości 4-6,5a / 100 mieszkań (il.3). Gdy za tak niewielki obszar zieleni ma odpowiadac grupa kilkuset mieszkanców, poczucie przynależności i odpowiedzialności rozmywa się. Problem stanowi także wysokość budynków, zwłaszcza w stosunku do małej powierzchni dziedzińca. Wypoczynek na 15-arowym obszarze zielonym w otoczeniu siedmio-kondygnacyjnej i wyższej zabudowy, ciężko nazwać komfortowym. Co gorsze, wspomniane dziedzińce czesto stanowią główne obszary przyrodnicze osiedla. Pozostałe to niewielkiej szerokości pasy niskiej zieleni ciągnące się wzdłuż granic terenu lub strefy buforowe między budynkami a miejscam postojowymi. To, jak bardzo mieszkańcom brakuje zieleni osiedlowej, jest widoczne w ich inicjatywach. Poprzez enriched with greenery and small architecture. They give the opportunity to relax in the near distan resident. This small distance plays a key role - it's easy to get out and come back according to your aceds [1], and each outgoing is an opportunity to contert the arrangement and buildings surrounding the courtyard and the the ber of inhabiants per neightyard and the numint buildings reduce the distance between the flot and the common part which makes it easier to make a decision about going outside. This is important regardless the type of building, not only quarterly. The lower number of inhabitants per urban interior space, the stronger the identification with the surrounding area and the sense of responsibility for the quality and aesthetics of the common space. The analysis of spatial layouts of selected contemporary housing estates shows that the area of open courtyards in relation to the number of apartments decreases by every investment. In case of the first implementation of the European Estate since 2002 (stage: London, Paris, Rome), there is 1000-1300 square meters of green areas per every 100 flats. The next stages (Athens, Amsterdam, Lisbon) gave 700-900 square meters of the courtyard per 100 apartments. In the newest in vestments in Cracow - Nowe Czyżyny - this indicator comes down to the value of 400-650 sq. meters / 100 inhabitants is responsible for such a smeral hundred greenery the sense of belonging and responsibilit is going to be blurred. The height of the buildings is also a big problem, especially in relation to the small area of the courtyard. Resting on a green area of 1500 sq. meters surrounded by seven-storey and higher buildings is difficult to be called a comfortable one What's worse, these courtyards are often the main natural areas of the entire estate. The remaining ones are small stripes of low greenery along the investment boundaries or buffer zones between buildings and parking spaces. The sense of lack of the housing estate greenery among residents is visible in their initiatives. By nurturing balcony flowers or applying il 3. Nowe Czyzyyny - zielony dziedziniec dostepny dla miesskańcíw (autor - K. Warzocha
ill. 3. Nowe Cryzyny - a green courtyard available to the residents (author - K. Warzocha)

il. 4. Osiedle Europejskie - rólinnośś wertykalna (autor - K. Warzocha)
iil. 4. Europejskie Estate - a vertical vegetation (author - K. Warzocha)

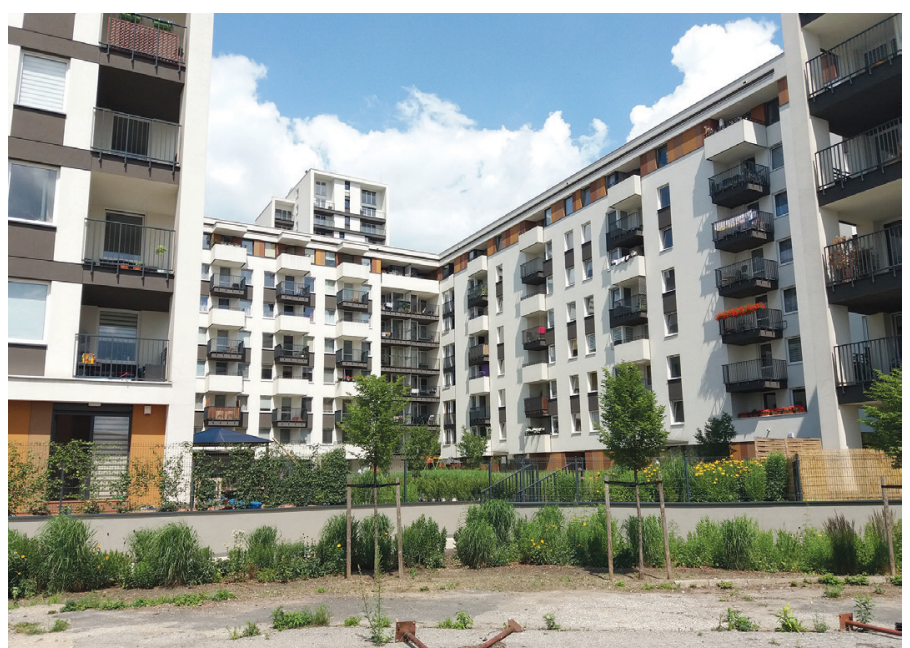

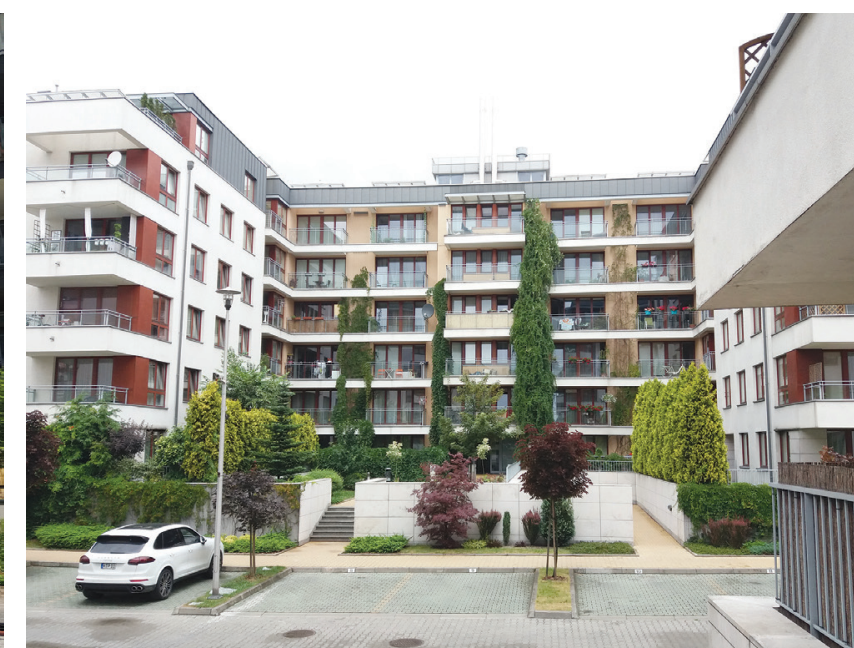


